\title{
Alternative Approaches in Evaluating the EU SME Policy: Answers to the Question of Impact and Legitimization
}

\author{
Robert K. Gruenwald
}

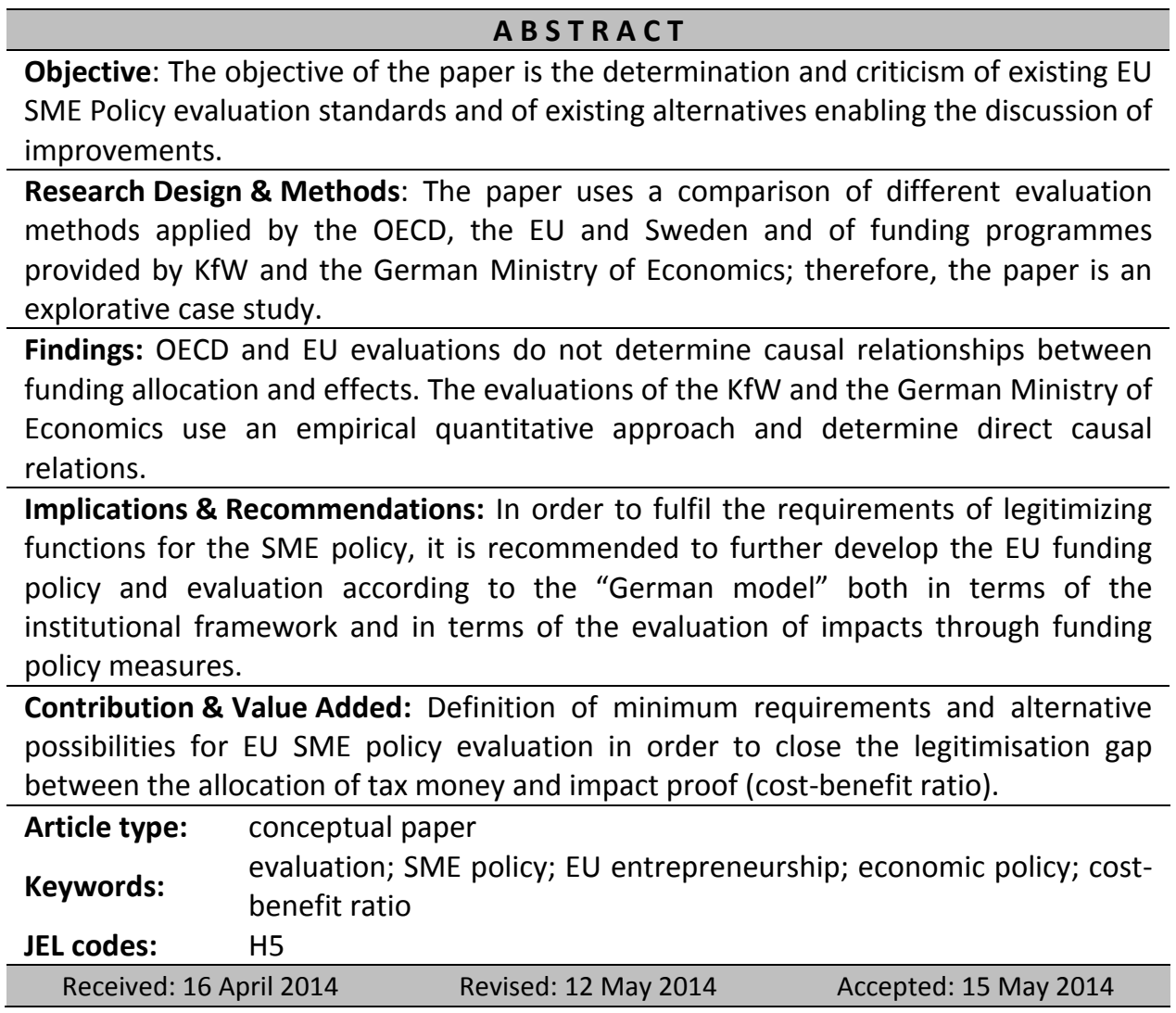

\section{Suggested citation:}

Gruenwald, R.K. (2014). Alternative Approaches in Evaluating the EU SME Policy: Answers to the Question of Impact and Legitimization. Entrepreneurial Business and Economics Review, 2(2), 77-88. 


\section{INTRODUCTION}

Evaluation is a "process that seeks to determine as systematically and objectively as possible the relevance, efficiency and effectiveness of an activity" (Papaconstantinou \& Polst, 1997, p. 9). Performance and result orientation is among the central goals of public sector modernisation guided by the New Public Management (Schedler \& Proeller, 2000). Neglecting the effect of cost-benefit-optimisation is becoming increasingly problematic in the face of a growing public attention. The success and efficiency of economic development programmes should be more transparent through resultoriented controlling and evaluation. The allocation of scarce resources could thus be optimised and better legitimised. The $\operatorname{OECD}(2007$, p. 10) postulates the application of evaluation and controlling in order to:

- optimise the impact of policies and programmes,

- make informed decisions about the allocation of funds, and

- achieve continued improvements in the design of programmes.

The traditional reasons for the legitimacy of government actions such as the principle of democracy and the rule of law have been increasingly supplemented in recent decades by a further legitimation requirement: the performance principle (Schedler \& Proeller, 2000, p. 61). Therefore, services and activities of the state must be increasingly legitimised due to their effects: evaluation and controlling is at least necessary for showing taxpayers and the business community that a funding programme is cost-effective (OECD, 2007, p. 10); therefore, evaluation should also be an integral part of the SME policy process.

Even though evaluation is often an integral part of many countries' policy development life cycle (Crowe, 2012, p. 245), researchers in this field note that SME policy-making is "often more ad-hoc and subjective than many people realize; it is not necessarily objective or rational" (Blackburn \& Schaper, 2012 p. 9). Evaluations are an instrument for legitimisation only if they describe and measure effects and results of programmes methodically (Schedler \& Proeller, 2000, p. 63).

However, it should be noted that relatively little literature on the subject is available. Academic research determines a lack of discussion about evaluation practices and methods concerning the economic impact of SME funding programmes (e. g. Curran, 2000; Pack \& Saggi, 2006; Greene \& Storey, 2007, chap. 12; Greene, 2009; Crowe, 2012; Wach, 2012, chap. 4). Essentially, available studies and models come from institutions such as the OECD and the EU Commission (OECD, 2004b; OECD, 2007; EIM Business \& Policy Research, 2004; EU, 2012a; EU, 2012b; OECD, \& EU, 2012; Paconstantinou \& Polt, 1997; Stockmann, 2000; Tödtling-Schönhofer et al., 2011; Wach, 2013; European Commission, 2002; Ramboll Management Consulting, 2011). The OECD notes that only very non-specific, general literature exists on the topic of evaluation, but none exists on economic policy evaluation standards or on common approaches (OECD, 2011, p. 114). Crowe (2012 p. 253) states that evaluation methods and procedures for fine-tuning SME policy programmes and measures have remained a postulation to academic research until today. 
The objective of the paper is thus to identify and then to constructively assess the existing EU SME policy evaluation standards compared to existing alternatives. The main research methods applied are a literature review (why and how should SME policy be measured), an explorative case study (what is measured in practice), and constructive criticism (what should be measured).

\section{LITERATURE REVIEW}

SME policy is a subcategory of economic policy. Economic policy means the practice of political actors in the economy and the scientific study of this practice (Acocella, 2000). Practical economic policy is based on two assumptions: the desirability and legitimacy of political action in the field of economy and the effectiveness of intervention in a market economy.

The first definition of economic policy takes place on the level of social and political objectives (i.e. on the level of desirability or determination of higher-level goals such as the promoting of prosperity). Below this general level the economic policy postulates the following operationalised goals (Peter, 2000, p. 82):

- What can be achieved?

- What should be achieved within the framework of achievable goals?

- What instruments are used respectively which goals are achieved?

- How can achieved objectives be determined?

On this level, economic policy can be defined as the allocation of scarce resources, guided by collective goal decisions with the assumption that the market is inefficient in certain areas (OECD \& EU, 2012, p. 35). If a specific market is efficient, then no political intervention is necessary or legitimised. Thus, the following economic policy target system can be defined for market economies with increasing operationalisability (Tuchtfeld, 1988, p. 183; Kevenhörster, 2006, p. 101):

1. general public welfare,

2. social policy: freedom, justice, security, peace,

3. promotion of national prosperity,

4. operationalised economic policy objectives: stability and growth,

5. stability and balanced structure: full employment, price stability, balance of payments equilibrium, balance of regional development, efficient market structure, competitive export industry, distributive justice, and sustainable development.

The general problem with such a target system is its empty formula character. Most of these goals are difficult or impossible to operationalise. In general, it can be said that the deeper one goes into this target system, the sooner goals can be operationalised. This level would be, for example, the EU SME policy as the operational level of general social and economic goals. The current EU general economic objectives are defined by the Council of the European Union in the "Europe 2020 Strategy". Four priority objectives were defined for 2020 (EU High Level Group, 2004, p. 6):

1. sustained economic growth,

2. more and better jobs, 
3. greater social cohesion,

4. introduction of sustainability.

The European Union Support Programmes for SMEs (2012) as the central document on the EU SME policy is only a budgeting document and does not provide any benchmarks or targets. Therefore, experts criticise that the achievement of objectives cannot be ascertained or controlled (Tödtling-Schönhofer et al., 2011, pp. 77, 81). The EU economic policy in general, and in particular the EU SME policy, provides only declaratory objectives and budgets; therefore, a study of the Directorate General for Internal Policies, commissioned by the EU parliament, reaches the conclusion that there is only "weak evidence on the effectiveness" of EU SME policy measures (TödtlingSchönhofer et al., 2011, p. 102).

Declaratory objectives are statements of intent without the definition of a target state and are a frequent political practice. Declaratory targets do not fulfil any of the following functions (Stockmann, 2000, p. 14).

1. Cognitive Function: decision-relevant data are collected in order to reach controlled decisions.

2. Control Function: The analysis of possible shortcomings of programmes needs quantitative data and target setting in order to compare differences between activities and targets for legitimisation.

3. Dialog Function: The results of an evaluation are the basis of a successful cooperation between different stakeholders (Najda \& Wach, 2005).

4. Legitimizing Function: It is possible to prove the correctness of the use of funds on the basis of data obtained.

Due to the fact that the EU SME policy provides no targets, apart from budgets, a target-performance comparison is not possible. Thus, the measurement of effectiveness in the allocation of common goods is not possible. Effectiveness can be described as the ratio of targets and goal achievement. A determination of the degree of goal achievement is impossible with qualitative goals (Schedler \& Proeller, 2000, p. 63). Objectives in economic policy can be distinguished by their target quality as follows (Fatás, Mihov, \& Rose, 2006, pp. 5, 30; Rosenblatt \& Kinder, 2006, p. 62):

1. Qualitative Targets: Usually inaccurately defined goals such as job security, reliable monetary policy and low government debt.

2. Comparative Targets: A comparison of the specification of a variable in the actual target comparison such as the temporal change of a size - for example the increase in exports by $x \%$ and the reduction of unemployment by $y \%$. Comparative objectives are therefore more accurate than qualitative goals.

3. Quantitative Targets: Accurate quantitative targets in absolute or relative numbers or as a target range.

Therefore, evaluation of SME policies first needs quantitative targets, not declarative targets (Wach, 2012). 


\section{MATERIAL AND METHODS}

The paper compares and assesses existing SME policy evaluation approaches and is as such an exploratory case study. Firstly, the objective is to find evaluation approaches from institutions, research groups, academic journals, conferences, organizations, and, secondly, to assess their usability for evaluation practice, because some studies only have a theoretical model character.

Only a few studies exist concerning the topic and only four applied evaluation approaches were found, mostly from major international organizations such as the OECD and the European Commission (EC) or from public policy consultant agencies. Different evaluation methods and metrics were used. The level of evaluations reaches from the analyses on a macro-economic level to a statistical analysis of a sample of companies based on financial metrics related to sustained SME subsidies.

In contrast to this, academic research focuses more on causal-logical models, not on metrics, mostly with the purpose of providing a framework for policy making (e. g. Hart, 2007; Wren, 2007; Lynch et al., 2009; Gruenwald, 2013; Gruenwald, 2014). Frequently, the problem is that only additional complexity is built up, but the question of how to impact remains unanswered. It is thus still criticised that academic research is only of limited use for the practice of SME policy evaluation. Even researchers conclude that "consistently authors use terms such as 'net economic benefit' and 'business performance' [...] but there is no real discussion as to what this means or how it could be measured" (Lenihan, 2011, p. 327). Therefore, it may be plausible to investigate the problem of SME policy impact measurement from the perspective of practitioners as it is pursued in the following exploratory case study.

The cases are selected according to their depth of documentation and availability. Case 1 analyses the SME Policy Index developed by the EU and the OECD. Case 2 reviews an alternative approach developed by the Swedish Agency for Growth Policy Analysis. Case 3 examines an approach developed by the EU commission service "DG Enterprise" which can be regarded as a suspended precursor of the SME Policy Index. Case 4 presents a best practice approach developed by Ramboll, a non-profit policy consultancy applied in German SME programmes.

In addition to the cases selected here, there are, of course, other approaches. The selected cases, however, are well documented and pursue opposite approaches in that they define different measurement levels: whereas the SME Policy Index (case 1) uses only macro data (mainly on a macro-economic level) and can thus only indirectly determine the success of specific SME policy measures, the other cases are graded according to their increasing use of micro data. Thus, case 4 represents an approach mainly tracking the impact of measures on a company level and provides a best practice example for measuring, not only estimating the impact.

The selected approaches are analysed in order to answer the following questions: What is measured? How is the evaluation purpose operationalised? How is it measured? Are appropriate metrics used and what are their limits? Are they clearly defined? Do the metrics measure what is claimed to be measured? 


\section{SME Policy Evaluation Case 1: SME Policy Index}

The European Union started a project called "SME Policy Index" in order to develop a systematic evaluation methodology for all programmes in 2004 (EIM Business \& Policy Research, 2004). In the field of economic development, the main result of this initiative seems to be the SME Policy Index established to measure the realisation of the so-called "Small Business Act for Europe" (SBA) adopted in 2008.

The SME Policy Index, developed by the OECD in collaboration with the EU (OECD, 2004a), determined to not only measure, but also provide guidance on how to improve SME policy (OECD \& EU, 2012, p. 68). As such, the index is part of the "Small Business Act" monitoring process (OECD \& EC, 2012, p. 68) for the enterprise policy performance assessment (OECD, 2012, p. 1). The SME Policy Index is based on an initiative by the OECD in 2007. Until today, the European Commission (EC) has used this instrument only for the assessment of the SME policies of Turkey, the Western Balkans, and the Eastern Partners, which are all not members of the EU (European Commission, 2012a, 2012b). It is striking that in these EC assessments only a few instruments of the OECD toolset were used. The toolset was reduced to ten SBA dimensions such as entrepreneurial learning, operation environment, public procurement, entrepreneurial skills etc. The SME Policy Index provides only an undefined best-practice level, which presumably seems based on OECD data in order to benchmark SME activities in dedicated countries. Further problems are:

1. The SME Policy Index does not deliver transparent results, as best-practice levels are not defined and the calculations are not documented,

2. The EC does not apply the SME Policy Index on its member countries and,

3. Any type of measures concerning a cost-efficiency ratio is non-existent. This is even more remarkable as the OECD principally recommends efficiency ratios as a key requirement for the evaluation of SME policies (e.g. OECD, 2007, p. 10) and for the final report "Review of methods to measure the effectiveness of state aid to SMEs" commissioned by the European Commission (EIM Business \& Policy Research, 2004, p. 39).

While the EU's investing of around 324 milliard EUR for SME promotion between 2007 and 2013 it does not measure the success of its SME support programmes, national SME policy evaluation approaches such as in Denmark, Sweden, and the United Kingdom exist - at least in some EU countries (OECD, 2011, p. 115).

\section{SME Policy Evaluation Case 2: IPREG-2}

The Swedish Agency for Growth Policy Analysis initiated the so-called IPREG ${ }^{1}-2$ project in 2010. Its objective was "to map the politics towards entrepreneurship and Small and Medium-sized Enterprises in Europe" (Swedish Agency for Growth Policy Analysis, 2011a, p. 6). The project executes "research leading to a better understanding of how entrepreneurship, innovation and small businesses can create sustainable economic growth in Europe and its constituent regions" (Swedish Agency for Growth Policy

\footnotetext{
${ }^{1}$ The abbreviation IPREG stands for "Innovative Policy Research for Economic Growth".
} 
Analysis, 2011a, p. 3). IPREG is a European network comprising researchers, policy makers and representatives from business organisations interested in Entrepreneurship and SME policy. In the frame of this network, the Swedish Agency for Growth Policy Analysis currently coordinates collaborative projects in Sweden, Austria, Poland, Belgium, and Spain. Its objective is to estimate the full costs and impact of entrepreneurship and SME policy (Swedish Agency for Growth Policy Analysis, 2011a, p. 3).

In 2011, the agency presented its first evaluation report on SME policies in the mentioned countries. The IPREG does not use a unified evaluation methodology. Only in the case of Poland and Flanders (Belgium) the agency does define an explicit evaluation methodology based on a cost analysis of public funding and the agency provides a "decision tree [...] to help civil servants in coping with the definition of costs" (Swedish Agency for Growth Policy Analysis, 2011b, p. 54). The result is, for example, a comparison of allocated money by categories (financing, innovation, etc.) and by policy areas (entrepreneurship, education and training, etc.) due to the fact that „Flanders and Belgium have lacked a quantification of costs for entrepreneurship and SMEs" (Swedish Agency for Growth Policy Analysis, 2011b, p. 77). The conclusion concerning the Flanders case is the following: the administration should focus on impact evaluation. The IPREG-2 does not provide a model for impact assessment in its evaluation, nor does it outline a way in which to execute an evaluation in order to measure the ratio of targets and goal achievement or a cost-efficiency ratio.

\section{SME Policy Evaluation Case 3: EU Commission Service}

The EU commission service "DG Enterprise" started an initiative in 2000 to establish evaluation standards for measuring the efficiency and effectiveness of the EU SME policy. After three evaluation reports no further reports were published.

Similar to the SME Policy Index, access to finance, regulatory and administrative environment, taxes and duties, the openness of markets, entrepreneurship, human capital development, the innovation rate, etc. were studied (European Commission Directorate General for Enterprise and Industry, 2004, p. 9). A total of nine main indicators were determined such as: (1) market capitalisation as a percentage of the GDP, (2) risk capital as a percentage of the GDP, (3) the number of business angel networks, (4) the amount of direct investment abroad, (5) state aid as a percentage of the GDP, (6) net changes in the stock of enterprises.

This selection of indicators already shows that the data were highly aggregated and should be regarded more as a national economic account. There was neither (1) is a link established between individual SME programmes and these indicators, nor (2) any statistical correlation calculated, nor (3) any synoptic overview of measures and budgets in certain areas provided, nor (4) any relationships between the development of indicators and policy measures assumed. Additionally, the data were retrieved from sources such as PriceWaterhouseCoopers, European Venture Capital Association, etc. (European Commission Directorate General for Enterprise and Industry, 2004, p. 25). Therefore, the data were highly aggregated on a macro-economic level, retrieved from secondary sources and were not collected within the framework of funding projects. One of the best examples was a UK entrepreneurship programme measuring funding impact 
with new VAT registrations as a proxy for a more entrepreneurial society (Cowie, 2012, p. 252).

However, the difference to the SME Policy Index is that this evaluation approach is transparent, in particular because it compares the characteristic values between the member countries on the basis of quantitative data and not, as in the case of the SME policy, with a benchmark of which the calculation remains unclear. Furthermore, this valuation provides "relevant quantitative targets" although they are not justified by theoretical models or derived from best practice cases. Mostly, the proposed targets are a list of policy targets of various EU member countries - or it seems they are a heuristic average of them. Thus, for example, it is defined the "self-employment rate" as "relevant quantitative target" with the objective of "increasing the number of self-employment rate of 353400 in the year 2002 to 380000 in the year 2006" (European Commission Directorate General for Enterprise and Industry, 2004, p. 66). Therefore, this evaluation approach provides at least an overview of possible target settings and allows benchmarking with other member countries without using an "imagery" benchmark, as in the case of the SME Policy Index. Yet, even here, it should be noted that no direct relationship between causes and effects are determined between SME policy measures and economic impact.

\section{SME Policy Evaluation Case 4: ERP Evaluation}

The German ERP innovation programme serves the long-term financing of marketoriented research and development (R\&D) for new products, processes or services. The cooperation of the SME sector with research institutions has funding priority. The ERP is handled by so-called "special credit institutions". In Germany, long-term state aid in the context of SME funding is awarded only by these "state" banks. The ERP programme is part of the services of the $\mathrm{KfW}^{2}$. The $\mathrm{KfW}$ is, with total assets of 495 milliard EUR (2011), the third largest German bank. The banking group covers over $90 \%$ of its borrowing needs in the capital markets. The KfW offers financing for entrepreneurship, enterprise development and innovation and covers the entire CLC (Touché, 2013, pp. 7, 8, 10, 13).

The ERP programme was evaluated in 2011, commissioned by the Federal Ministry of Economics and Technology and executed by Ramboll Management Consulting, a consulting company for contracting authorities in Germany. Questions of the evaluation, referred to as "impact analysis", were (Ramboll, 2011, p. 2): (1) Were ERP programme objectives to be achieved? (2) Can differences between assisted and non-assisted firms be identified?

The methodological basis for the evaluation is a survey of 1600 companies participating in the ERP programme and a survey of 500 non-participating firms, as well as a survey of nearly 200 financial advisors from corporate banks (Ramboll, 2011, p. 2). In addition to this, the KfW SME panel was included. The database of the $\mathrm{KfW}$ can be seen as "rich data" for research. In 2004, the KfW started a data analysis in combination with a survey. The sample includes financial data of more than 10000 companies and

\footnotetext{
${ }^{2}$ The $\mathrm{KfW}$ is a German government-owned development bank based in Frankfurt.
} 
additionally, interviews with 2000 CEOs of the companies from the financial data set (Bindewald, 2004, p. 50).

Based on this comprehensive set of financial data from companies participating in the ERP programme and non-participating companies, the evaluation provides indicators such as "sales development" and "expected sales trend", "profit performance" and "expected profit improvement", "profit ratio to total loans", etc. With the help of this, precise measurement of the grant funding impact on the company's success and of the impact on employment is possible. Furthermore, the financial and employment effects of various grants can be measured (Ramboll, 2011, pp. 79, 81, 84).

The evaluation thus provides indicators such as (1) the average ERP loan amount per job created and workplace secured (in this case: 67674 EUR funding costs per job created and 15741 EUR per job protected; Ramboll, 2011, p. 86), (2) the degree of target achievement against quantitative objectives for each individual indicator (Ramboll, 2011, p. 93) and (3) the quantification of dead-weight effects (inefficiency of granted funds) (Ramboll, 2011, p. 94).

\section{IMPLICATIONS AND RECOMMENDATIONS}

From the four evaluation approaches presented in this paper, the following conclusions can be drawn.

1. The use of macro data is simply pointless. It does not allow linking funding allocation with effects.

2. The use of micro data is usefull. Although collection is a more extensive process (compiling of surveys and financial data), micro data allow the determination of correlations between funding allocation and the micro level impact.

3. The use of micro data for an evaluation requires that only a few institutions are charged with funding allocation. These should be banks, not administrations, because the allocation of financial resources is the core competency of banks. Additionally, this includes the extensive collection and analysis of financial data in the daily business process and the expertise in using them.

Thus, efficiency and effectiveness in terms of cost-benefit relations can be measured and used to establish target systems with precise quantitative targets instead of declaratory objectives which do not allow the determination of degrees of target achievement and the return on funding. Therefore, it seems evident that the Ramboll approach provides a best practice example for the SME policy evaluation which delivers a precise measurement of impact generated with the tax payer's money and can thus legitimise state interventions in favour of SMEs in market societies.

\section{CONCLUSIONS}

As mentioned in the introduction, research and literature on the subject are not extensive, at least in terms of publicly accessible findings, models, and studies. Nevertheless, based on the literature presented here, it can be determined that: 
1. in order to legitimise SME policy, it is necessary to collect comprehensive data on the micro level (company level),

2. in order to ensure this, the circle of institutions must be limited to only a few funding donors. This is especially true for the diverse regional EU funding channels. It is advisable to follow the German model and to establish one or two special funding banks in every member state.

Based on this, a quantitative target system can be developed not only on "weak" benchmarks at the country macro-economic level, but on a precise SME policy evaluation standard that measures actual - and not only assumed - effects on employment rate, corporate success, and cost-efficiency ratios on an empirical bases. Thus, SME policy can fulfil legitimisation and controlling requirements as well as provide the basis for an informed stakeholder dialogue.

\section{REFERENCES}

Acocella, N. (2000). The Foundations of Economic Policy: Values and Techniques. Cambridge: Cambridge University Press.

Bindewald, A. (2004). Was können gescheiterte von erfolgreichen Unternehmen lernen: Ergebnisse einer explorativen Datenanalyse von DtA-finanzierten Unternehmen. In KfW Bankengruppe (Ed.), Was erfolgreiche Unternehmen ausmacht: Erkenntnisse aus Wissenschaft und Praxis (pp. 49-88). Heidelberg: Physica.

Blackburn, R. A., \& Shaper M. T. (2012). Introduction. In Government, SMEs and Entrepreneurship Development: Policy, Practice and Challenges. In R. A. Blackburn, \& M. T. Schaper (Eds.), Government, SMEs and Entrepreneurship Development: Policy, Practice and Challenges (pp. 7-16). Farnham: Gower Publishing.

Corew, P. (2012). SME Policy Evaluation: Current Issues and Future Challenges. In R. A. Blackburn, \& M. T. Schaper (Eds.), Government, SMEs and Entrepreneurship Development: Policy, Practice and Challenges (pp. 243-256). Farnham: Gower Publishing.

Curran, J. (2000). What is small business policy in the UK for? Evaluation and assessing small business policies. International Small Business Journal, 18(3), 36-50.

Daszkiewicz, N., \& Wach, K. (2012). Internationalization of SMEs: Context, Models and Implementation. Gdańsk: Gdańsk University of Technology Publishers.

EIM Business \& Policy Research. (2004). Review of methods to measure the effectiveness of state aid to SMEs: Final report to the European Commission, EIM White Paper, Retrieved on January 13, 2014, from: http://ec.europa.eu/enterprise/newsroom/cf/_getdocument.cfm ?doc_id $=415$

EU High Level Group (2004). Facing the Challenge: The Lisbon Strategy for growth and Employment. Brussels: European Communities Publication.

European Commission (2002). Qualitative Ziele der Unternehmenspolitik: Schritte zur Verwirklichung der Ziele von Lissabon (COM (2002)610 final). Brussels: EU Publishing.

European Commission (2012a). SME Policy Index: Eastern Partner Countries 2012. Paris: OECD Publishing.

European Commission (2012b). SME Policy Index: Western Balkans and Turkey 2012. Paris: OECD Publishing. 
European Commission Directorate General for Enterprise and Industry (2004). Benchmarking der Unternehmenspolitik (Arbeitsdokument der Kommissionsdienststellen SEK (2004) 1427). Brussels: EU Publishing.

Fatás, A., Mihov I., \& Rose A.K. (2006). Quantitative Goals for Monetary Policies (Working Papers Series Nr. 615, April 2006). Frankfurt: European Central Bank.

Greene, F. J. (2009). Assessing the impact of policy interventions: the influence of evaluation methodology. Environment and Planning C: Government and Policy, 27(2), 216-229.

Greene, F. J., \& Storey, D. J. (2007). Issues in evaluation: The case of Shell Livewire. In D.B. Audretsch, I. Grilo, \& A. R. Thurik (Eds.), Handbook of research on entrepreneurship policy. Cheltenham: Edward Elgar Publisher.

Gruenwald, R.K. (2013). Entrepreneurship Challenges in High-Growth Companies and Consequences for SME Policy. Entrepreneurial Business and Economics Review, 1(1), 41-54.

Gruenwald, R.K. (2014). Shaping policy supporting high-growth entrepreneurship: reflections on EU SME Policy. Horyzonty Polityki, 5(10), 105-126.

Lenihan, L. (2011). Enterprise policy evaluation: Is there a 'new' way of doing it?. Evaluation and Program Planning, 34, 323-332.

Hart, M. (2007). Evaluating EU Regional Policy: how might we understand the causal connections between interventions and outcomes more effectively?. Policy Studies, 28(4), 295-308.

Kevenhörster, P. (2006). Politikwissenschaft: Band 2 Ergebnisse und Wirkungen der Politik. Wiesbaden: VS Verlag/GWU.

Klump, R. (2011). Wirtschaftspolitik: Instrumente, Ziele, Institutionen. Munich: Pearson.

Lynch, N., Lenihan, H., \& Hart, M. (2009). Developing a framework to evaluate business networks: the case of Ireland's industry-led network initiative. Policy Studies, 30(2), 163-180

Najda, M., \& Wach, K. (2005). Impact of integrated European business environment on SMEs cooperation strategies. Ekonomia, 17, 123-139.

OECD (2004a), Promoting Entrepreneurship and Innovative SMEs in a Global Economy: Towards a More Responsible and Inclusive Globalisation. Paris: OECD Publishing.

OECD (2004b). Evaluation of SME Policies and Programmes. Paris: OECD Publishing.

OECD (2007). OECD Framework for the Evaluation of SME and Entrepreneurship Policies and Programmes. Paris: OECD.

OECD (2011). OECD Studies on SMEs and Entrepreneurship: Thailand. Paris: OECD Publishing.

OECD (2012). SME Policy Index: Eastern Partner Countries. Paris: OECD Project Factsheet.

OECD, \& EC (2012). SME Policy Index: Eastern Partner Countries 2012: Progress in the Implementation of the Small Business Act for Europe. Paris: OECD Publishing.

Pack, H., \& Saggi, K. (2006). Is there a case for industrial policy? A critical survey. The World Bank Research Observer, 21(2), 267-297.

Paconstantinou, G., \& Polt, W. (1997). Policy evaluation in innovation and technology: an overview. In OECD (Ed.). Policy Evaluation in Innovation and Technology: Towards Best Practices (p. 914). OECD Publishing: Paris.

Peter, H. (2000). Wirtschaftspolitik. Oldenbourg: Munic.

Ramboll Management Consulting (2011). Evaluierung der ERP-Programme: Endbericht (Studie im Auftrag des Bundesministeriums für Wirtschaft und Technologie), Retrieved on February 12, 2014, from http://www.bmwi.de/BMWi/Redaktion/PDF/Publikationen/evaluierung-erpprogramme, property=pdf, bereich=bmwi2012,sprache $=$ de, $r w b=$ true.pdf 
Rosenblatt, M., \& Kinder, J. (2006). Canadian and UK Innovation Policies: A Comparative Analysis. In Doern, G. (Ed.). Innovation, Science, Environment: Canadian Policies and Performance 2006-2007 (pp. 59-81). Montreal: McGill-Queen's University Press.

Schedler, K., \& Proeller, I. (2000). New Public Management. Bern: UTB.

Stockmann, R. (2000). Evaluation in Deutschland. In Stockmann, R. (Ed.), Evaluationsforschung: Grundlagen und ausgewählte Forschungsfelder (pp. 11-40). Opladen: Waxmann.

Swedish Agency for Growth Policy Analysis (2011a). Entrepreneurship and SME Policies across Europe: Estimating the Costs of Entrepreneurship and SME Policies in Sweden (Implementation Report, Working Paper 2011:21), Retrieved on February 11, 2014, from http://www.tillvaxtanalys.se/download/18.56ef093c139bf3ef8902a0b/1349864227474/WP _2011_21.pdf

Swedish Agency for Growth Policy Analysis (2011b). Entrepreneurship and SME Policies across Europe: The Cases of Sweden, Flanders, Austria, and Poland (Working Paper 2011:03), Retrieved on February 11, 2014, from http://www.tillvaxtanalys.se/download/18.56ef093c 139 bf3ef89029bb/1349864032808/Rapport_2011_03.pdf

Tödtling-Schönhofer, J., Hamza Ch., Resch A., Polverari, L., \& Bachtler J. (2011). Impact and Effectiveness of Structural Funds and EU Policies Aimed at SMEs in the Region (European Parliament Policy Department Structural and Cohesion Policies). Brussels: European Parliament Publishing.

Touché, B. (2013). Aktuelle Entwicklungen der KfW Förderung, KfW Präsentation auf dem b.b.h. Bundeskongress. Bonn: KfW.

Tuchtfeld, E. (1988). Wirtschaftspolitik. In Handwörterbuch der Wirtschaftswissenschaft (Vol. 9, pp. 178-206). Stuttgart: UTB.

Wach, K. (2012). Europeizacja małych i średnich przedsiębiorstw: rozwój przez umiędzynarodowienie. Warszawa: PWN.

Wach, K. (2013). An empirical investigation into the EU policy in favour of business succession among Polish family firms. Horyzonty Polityki, 4(9), 107-133.

Wren, C. (2007). Reconciling practice with theory in the micro-evaluation of regional policy. International Review of Applied Economics, 21(3), 321-337.

\section{Author}

\section{Robert K. Gruenwald}

Bachelor in Business Administration from the FOM University for Economics and Management (Fachhochschule für Oekonomie und Management, FOM) in Essen (Germany), Master in Accounting and Finance from the FOM University of Economics and Management in Essen (Germany); currently PhD student in Entrepreneurship (Cracow University of Economics, Poland); CEO of eCollect AG (Switzerland), Financial Technology \& Services.

\section{Correspondence to:}

Robert K. Gruenwald, B.A., M.A.

PhD Student at the Cracow University of Economics

gruenwald@gmx.ch 